\title{
Importance and the Zone of Tolerance of Customer Expectations of Fast Food Services
}

\author{
Domingos Fernandes Campos \\ UniversidadePotiguar \\ domingos_campos@uol.com.br \\ Kleber Cavalcanti Nóbrega \\ UniversidadePotiguar \\ klebercn@unp.br
}

ABSTRACT: This article analyzes the relationship between the importance of attributes for service quality and the tolerance zone between the desired and the minimum acceptable levels for customer expectations. The empirical study, conducted with 500 students, fast food customers, confirms that, as the importance of attributes increases, the tolerance zone gets closer and higher.

\section{INTRODUCTION}

Evaluations of service quality have pointed out limitations in the accurate measuring of customer perceptions due to the following factors: customer perception variability (PARASURAMAN et al, 1994; BROWN, 1997; CHIOU et al, 2005), and imprecise scales (YANG et al, 2004; BEHARA et al, 2002; DENG, 2008). The service operations, which include characteristics such as heterogeneity, intangibility, production-consumption simultaneity, and customer presence, increase the need for precise instruments to identify service attributes, as well as the evaluation of the quality of services rendered (GRÖNROOS, 1995; NOBBREGA, 1997; LOVELOCK, 2006; FITZSIMMONS, 2005).

Zeithaml et al (1993) recognize the existence of a zone of tolerance between desired service and adequate service. In this tolerance zone, the authors defend two hypotheses: first, the most important attributes for customers have narrower tolerance zones; second, they also have expectation limits closer to the maximum of the scale used. Although these propositions by the authors represent an important contribution, they result from theoretical analysis, supported by focus group research. The authors suggest, indeed, more research in order to operationalize these domains.

Other authors dealed with the problem of tolerance zone (JOHNSTON, 1995; WIRTZ and MATTILA,
2001; YAP and SWEENEY, 2007; NADIRI, 2007; CAVANA and CORBETT, 2007; AHMED, 2009), but there seems to have few empirical contributions on Zeithaml et al prior propositions. The objective of the present study is to evaluate these two hypotheses defended, using fast food services in a shopping center as the object of study, and based a sample of responses by 500 university students. The research also allows us to identify the main attributes of fast food service for the customers studied.

For the purpose of this research, the definition of "fast food" adopted was: commercial establishments that sell food and drink for immediate consumption in the locale or surrounding locale, which shares space with other fast food companies, or for consumption in any locale, usually specializing in pizza, sandwiches and chicken based foods (GOYAL and SINGH, 2007). The fast food products are distinguished from others in function of the following characteristics: being low priced, served quickly, usually eaten with the hands, easily packaged, and having a short shelf life (PRICE, 1997).

\section{PRECURSORS}

The idea of comparing the expected quality with the quality experienced, align with the vision of service quality as the relationship between perception and 
expectations about services offered (PARASURAMAN et al, 1985), (CRONIN and TAYLOR, 1992). The work of Parasuraman et al represent a peak in the understanding of service quality as the comparison, by the customer, of his expectations with the perception of services rendered. Even though intangibility in the services and subjectivity present difficulties, one can still look for service specification in the operational and measureable attributes. Grönroos (1982) proposed to systematize the perceptions of customers about service in seven characteristics: professionalism and capacity, attitudes and behavior, accessibility and flexibility, reliability and integrity, recuperation of service, panorama of service, and finally, reputation and credibility. Later, Parasuraman et al (1988) developed the SERVQUAL scale and condensed the determinants of quality into five dimensions: tangible aspects, reliability, responsiveness, safety and empathy.

Some studies about service quality, specifically in relation to fast food, contributed to the present study. Mersha and Adlakaha (1992) in research with 309 MBA students in the USA, brought to light the importance of attributes for some types of services, among them fast food. The results indicated that the four main factors are: speed of service, interest in correcting errors, reasonable prices and a pleasing environment. Kara et al (1997) completed a study about the factors regarding the choice of a fast food restaurant in the USA and Canada. The data for this study were collected through 320 self-administered questionnaires, which had been distributed to 200 households in the USA and in Canada. In the USA, regular customers mainly value factors such as variety, speed, and friendly staff, while occasional customers favor price and promotions. In Canada, regular customers prioritize convenience of location and availability of nutritional information, while occasional customers favored price, location and novelties.

Brady and Robertson (1999) investigated 309 fast food consumers in Ecuador and USA. They found results indicating more affectively-orientation in Ecuadorian costumers, while USA ones prioritize cognitive processes, looking like a more professional perception of service value. Gupta and Chen (1995) used a Likert 7 points scale in fast food context to prioritize SERVQUAL dimensions. The respondents, classified, in a decreasing scale of importance: reliability, assurance, tangibles, responsiveness and empathy.

Differently, Johnson and Mathews (1997), when using SERVQUAL scale to survey about should and wills fast food customers expectations, did not find reliability as the most important dimension, but security. Access appears as the highest will expectation. They surveyed 389 business school undergraduate students in England. Lee and Ugaldo (1997) completed research in the USA and South Korea, with the intention of identifying the cultural implications in the evaluation of fast food services, using questionnaires based on SERVQUAL. The data collected together with the students in administration courses in the two countries showed higher expectations for the Koreans than for the North American students - notably in relation to physical aspects, reliability, guarantee and low prices.

For Liu and Chen (2000), social surroundings greatly affected the importance of good value for money, food taste/flavor, variety of food offerings, music and noise level, attractive décor, atmosphere and ambience, friendly and pleasant staff, and cleanliness and neatness. The common tendency is an increase in the importance of these variables as the situation changes from alone, to with friends and highest if with clients. Law et al (2004) surveyed eight quality factors affecting customer satisfaction. They found results indicating that waiting time and other service factors such as staff attitude, environment, seat availability and food quality significantly influence the customers' return frequency.

Gilbert et al (2004) surveyed 5,136 fast food customers in a cross-cultural comparison evolving five globallyfranchised fast-food chains in four countries - Jamaica, Scotland, USA and Wales. Academicians of these four countries trained graduate and undergraduate students to administer the customer satisfaction survey. Baek, Ham and Yang (2006) surveyed 303 korean students, and 329 filipino students, in order to identify the importance of attributes in the selection of fast food restaurants. Koreans and filipinos viewed menu price as the most important attribute. The following attributes, in Korea, were brand, food related factors and service- and hygiene-related factors. In Philippines, the subsequent attributes were food-related factors, service- and hygiene-related factors and brand.

In a study completed with 120 consumers from a fast food chain in Brazil, Machado et al (2006) found that the attributes with the highest levels of expectation were: polite staff, well prepared and cooked food, and efficient supply of supplements, adequate product temperature, tables cleared and cleaned quickly, and a well dressed staff. Goyal and Singh (2007) con- 
ducted research about fast food in India, consulting 171 university students, having as its objective the identification of factors that influence them in the choice of a restaurant, they found the following hierarchy: variety, quality and flavor of the food, environment and hygiene, speed, price and location.

Qin and Prybutok (2009) investigated the relationship among service quality, food quality, perceived value, customer satisfaction and behavioral intentions in fast-food restaurants. They surveyed 305 USA college students in USA. The results indicated that reliability/responsiveness, tangibles, assurance, and recovery are slightly more important than empathy. Fresh, tasty, and a variety of food and beverages remains are considered to be important criterion for satisfying customers. In this way, the model by Liljander and Strandvik (1995) introduces the relation among the acts of service and relationships. In a broadening spectrum, acts comprise episodes, which establish sequences that generate relationships. Thus, each act of service is relevant to the formation of customer perception about service. These episodes are also called the service encounters, service contacts, or moments of truth (NORMANN, 2001; ZEITHAML and BITNER, 2003; FITZSIMMONS, 2005).

The importance of service contacts derives, above all, the presence of customers and the service production-consumption simultaneity. The quality of the service is perceived in service contacts, having been created in the moment of or beforehand. Bitner et al (1997) defend that service contacts provoke the consumer to evaluate the level of service provided by the organization, by its staff and even interactions with other customers during a certain period of time. For Bitner and Brown (2000) and Harris et al (2003), the influence of service contacts can be divided in two main components: personal interactions with the service provider, and with the physical environment of the organization. The expectations and the quality of service are influenced by some aspects present in the service contacts: décor, smell, design, and music (COX et al, 2003; COYE, 2004). Keng et al (2007), when investigating the impacts of service en- counters on customer experiential value in a shopping mall, in Taiwan, registered that service contacts and the value the customer gives of the experience have been studied separately, and they completed a study integrating service contacts, the consumer experience, and the behavior intentions of the consumer in the context of a shopping center.

\section{METHODOLOGY}

The classic work of Zeithaml et al (1993), in response to the criticism about the use of SERVQUAL methodology, recognizes the limitation of evaluating the necessities for a single value. Thus, the expectations in relation to service can be represented by a strip or zone of tolerance. These expectations vary according to the attributes evaluated and would be different from customer to customer. The authors point to limits of the tolerance with regard to service desired (SD) and adequate or minimum service (SM). The first represents the level of the service provided that the customer would like to receive; the second reflects the minimum level of service that the customer would tolerate. Inside these limits, in the perception of the customer, a comfort zone is established for the receipt of service.

The tolerance zone can be established by the customer expectations for a determined service attribute, even if it is not delivered. When the service rendered effectively occurs, the customer evaluates the level of service received/perceived, through his or her own perceptions. The present construct being defined proposes to evaluate two affirmations of Zeithaml and Bitner (2003). In the first, customers affirm a narrower zone of tolerance for those attributes that they find more important. That is to say, the more important the attribute to the customer, the closer the limits SD and SM will be. Second, the customers affirm higher limits of tolerance for more important attributes. Thus, the more important the attribute, the closer SD and SM will be to the higher limit of the evaluation scale used. Figure 1 illustrates these precepts of the authors, evaluated in this study, which can be established according to the following hypothesis. 
Figure 1 - Relation between importance and expectations.

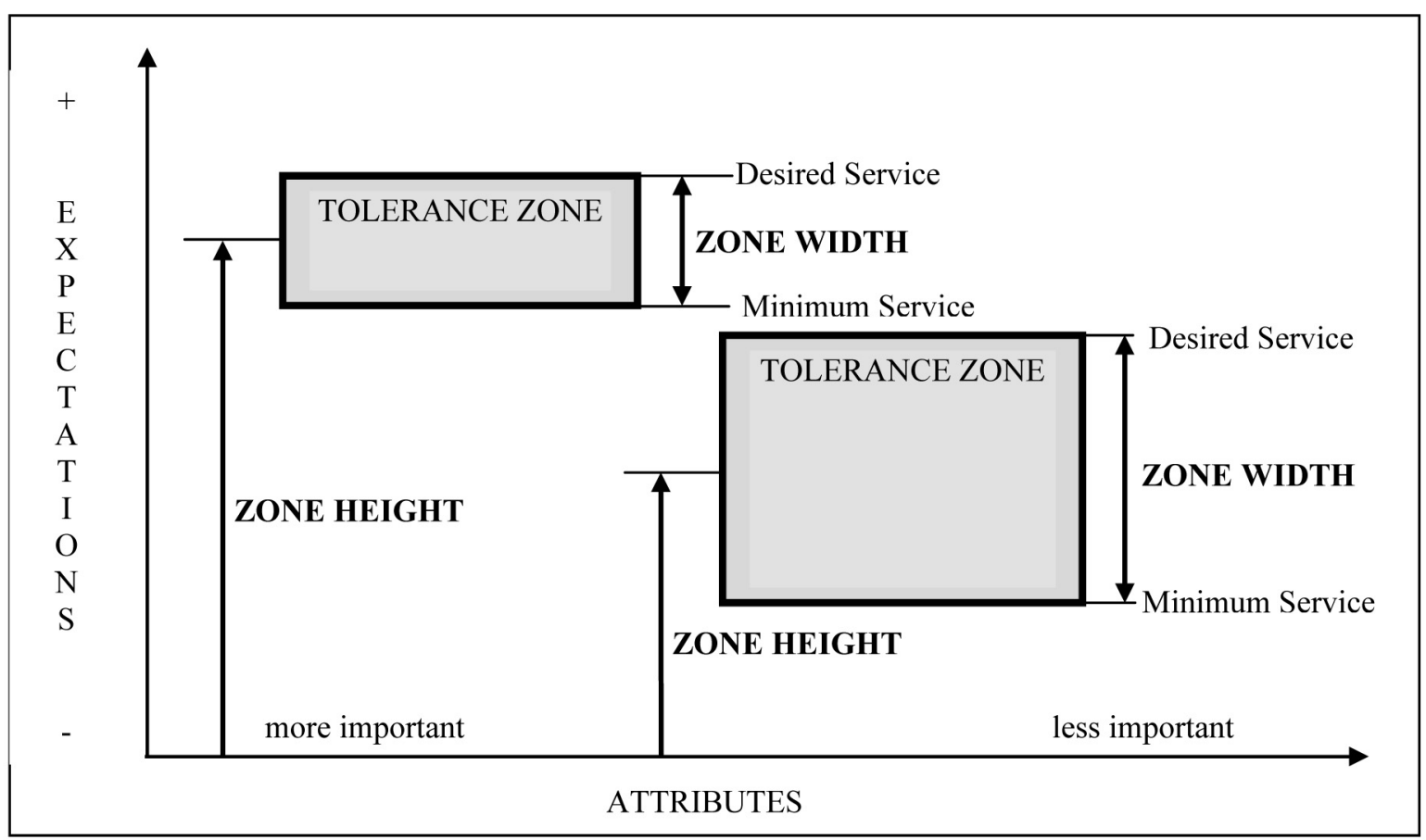

Source: adapted from Zeithaml and Bitner (2003)

H1: Attributes that are more important to customers have a narrower zone of tolerance.

H2: Attributes that are more important to clients have limits of expectations closer to the maximum utilized on the scale.

\section{MEASURING THE IMPORTANCE OF EXPECTA- TIONS}

On the one hand, the degree of the importance of the attributes can be found from the accurate measurement as expressed by the user. The tolerance zone height $(A l t \mathrm{Z})$, with a relative position in relation to the expectation scale, can be calculated by its average point, i.e., the average between the values of the desired service $(S D)$ and the minimum service $(S M)$ for each attribute. On the other hand, the width of the tolerance zone $(\operatorname{Larg} Z)$ of an attribute corresponds to the difference between the level of desired service and the level of minimum service. Algebraically, for a sample size $\mathbf{n}$, the average values are determined by:

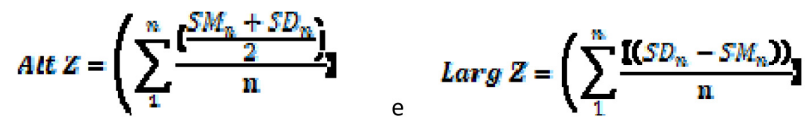

\section{FAST FOOD RESTAURANTS}

The evaluation of the hypothesis was based on the services offered in fast food restaurants in the commercial and entertainment center located in the city of Natal, Brazil. The shopping center is $231,000 \mathrm{~m}^{2}$, parking for 3,500 vehicles, 10 anchor stores, 1 supermarket and 210 satellite stores. It hosts a cinema complex with seven screening rooms. There are 35 restaurants. Sixteen of them fit into the definition of fast food and offer cuisine varying from conventional sandwiches to traditional Italian and Japanese dishes. There are local companies and franchises linked to national and international chains present all over the nation.

\section{MAPPING THE SERVICE CYCLE AND THE AT- TRIBUTES LIST}

Mapping the service cycle helps to identify and discover all of the important processes of an activity. Regarding an activity with high user contact, the service cycle analysis of fast food, from the customer's arrival to his or her departure, presents a set of attributes at each step in the process. For the mapping and analysis of the activities, the authors used direct observation and tried various restaurants listed, as well as used literature basis (NICK and HOWARD, 1998; BOJANIC, 2007; BOURANTA et al, 2009). Figure 2 shows the most important stages in the fast food service cycle. 
Figure 2 - Typical fast food service cycle.

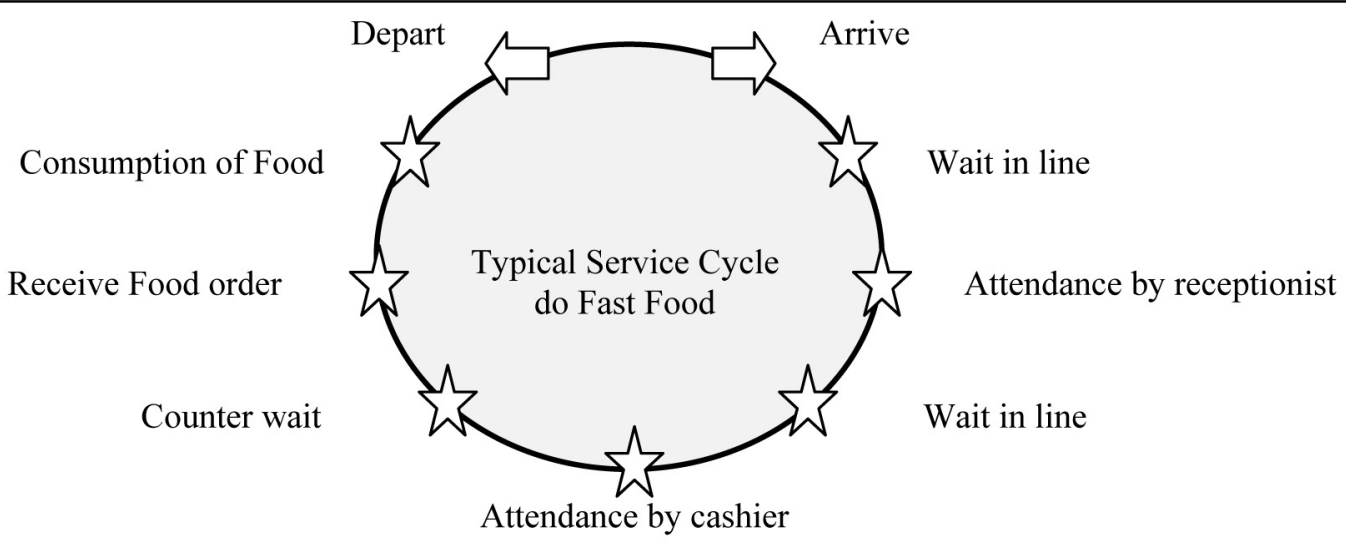

Source: research

For each activity in the service cycle, the attributes that the authors found relevant were listed, without any previous screening. Supported by attributes present in the studies shown in Table 1, a set of 45 variables was consolidated and systematized. The consolidation reflects an articulation between the analysis of the service cycle and the moments of truth.

Table 1 - Sources of questionnaire attributes.

\begin{tabular}{|c|c|c|c|}
\hline \multicolumn{2}{|r|}{ Author } & $\begin{array}{c}\text { Dimension/Attribute - Model/ } \\
\text { Scale }\end{array}$ & $\begin{array}{l}\text { Country (Sample) } \\
\text { Number of variables }\end{array}$ \\
\hline \multicolumn{2}{|c|}{ Mersha and Adlakha (1992) } & $\begin{array}{l}\text { Reliability, responsiveness, } \\
\text { assurance, empathy, } \\
\text { service time, value, ambience - } \\
\text { No servqual, Likert } 5 \text { points }\end{array}$ & $\begin{array}{l}\text { USA (316) } \\
12\end{array}$ \\
\hline \multicolumn{2}{|l|}{ Gupta and Chen (1995) } & $\begin{array}{l}\text { Tangibles, reliability, } \\
\text { responsiveness, assurance, } \\
\text { empathy - Servqual, Likert } 7 \\
\text { points }\end{array}$ & $\begin{array}{l}\text { USA (65) } \\
22\end{array}$ \\
\hline \multicolumn{2}{|c|}{ Kara, Kaynak and Kucukemiroglu (1995) } & $\begin{array}{l}\text { Empathy, price, service time, } \\
\text { convenience, hygiene, novelties } \\
\text { for children - } \\
\text { No servqual, Likert, } 5 \text { points }\end{array}$ & $\begin{array}{l}\text { Canada (141), USA } \\
(179 \\
11\end{array}$ \\
\hline $\begin{array}{l}\text { Johnson and Mathews } \\
\text { (1997) }\end{array}$ & $\begin{array}{l}\text { Tangibles, reliability, } \\
\text { responsiveness, credibility, } \\
\text { competence, courtesy, } \\
\text { communication, access, knowing } \\
\text { the customer, recovery, security - } \\
\text { Servqual, Likert } 11 \text { points }\end{array}$ & $\begin{array}{l}\text { England (389) } \\
11\end{array}$ & \\
\hline Lee and Ulgado(1997) & $\begin{array}{l}\text { Tangibles, reliability, } \\
\text { responsiveness, assurance, empathy, } \\
\text { price, service time, location - } \\
\text { Servqual, Likert } 9 \text { points }\end{array}$ & $\begin{array}{l}\text { Korea (89), USA (104) } \\
26\end{array}$ & \\
\hline $\begin{array}{l}\text { Brady and Robertson } \\
\text { (1999) }\end{array}$ & $\begin{array}{l}\text { Sacrifice, overall service quality, } \\
\text { service value, } \\
\text { behavioural intentions - } \\
\text { No servqual, Likert, } 9 \text { points }\end{array}$ & $\begin{array}{l}\text { Ecuador (116), USA (309) } \\
12\end{array}$ & \\
\hline
\end{tabular}




\begin{tabular}{|c|c|c|}
\hline Liu and Chen (2000) & $\begin{array}{l}\text { Speed service, food, price, } \\
\text { ambience, variety, music and noise, } \\
\text { promotional items - } \\
\text { No servqual, no Likert }\end{array}$ & $\begin{array}{l}\text { Philippines (1365) } \\
10\end{array}$ \\
\hline Law et al (2004) & $\begin{array}{l}\text { food, price, variety, ambience, } \\
\text { service time - } \\
\text { No servqual, Likert } 5 \text { points }\end{array}$ & $\begin{array}{l}\text { Hong Kong (106) } \\
8\end{array}$ \\
\hline Gilbert et al (2004) & $\begin{array}{l}\text { Reliability, responsiveness, } \\
\text { assurance, empathy, price, service } \\
\text { time - No servqual, Likert } 5 \text { points }\end{array}$ & $\begin{array}{l}\text { Jamaica (1581), USA (2399) } \\
\text { Scotland (585), Wales (571) } \\
17\end{array}$ \\
\hline $\begin{array}{l}\text { Baek, Ham and Yang } \\
\text { (2006) }\end{array}$ & $\begin{array}{l}\text { Brand, price, food, service and } \\
\text { hygiene - } \\
\text { No servqual, no Likert }\end{array}$ & $\begin{array}{l}\text { Korea (303) } \\
\text { Philippines (2329) } \\
12\end{array}$ \\
\hline Machado et al (2006) & $\begin{array}{l}\text { Tangibles, reliability, } \\
\text { responsiveness, assurance, empathy, } \\
\text { food - Servqual, Likert } 7 \text { points }\end{array}$ & $\begin{array}{l}\text { Brazil (120) } \\
20\end{array}$ \\
\hline $\begin{array}{l}\text { Goyal and Singh } \\
\text { (2007) }\end{array}$ & $\begin{array}{l}\text { Variety, food, ambience and } \\
\text { hygiene, price, location - No } \\
\text { servqual, Likert } 5 \text { points }\end{array}$ & $\begin{array}{l}\text { India (171) } \\
7\end{array}$ \\
\hline $\begin{array}{l}\text { Qin and Prybutok } \\
(2009)\end{array}$ & $\begin{array}{l}\text { Food, service, perceived value - } \\
\text { Servperf, Likert } 7 \text { points }\end{array}$ & $\begin{array}{l}\text { USA (282) } \\
40\end{array}$ \\
\hline
\end{tabular}

\section{Source: research}

Table 2 presents the attributes related to each activity in the cycle. The column to the right reflects the framing of each attribute according to the dimensions established by Parasuraman et al (1988). The asterisk $\left({ }^{*}\right)$ on some of the attributes indicates that this same attribute can be perceived, also, in other steps in the cycle.

Table 2 - Attributes identified from the typical fast food service cycle.

STAGES

Arrival/
Approach

Approach

Attendance with the receptionist
ATTRIBUTE

- Visual attractiveness of the store

- Brand strength (recognition and trust in the brand)

- Level of frequency (regular or occasional frequency)

- Location in relation to the food court

- Availabilty of lunches and dishes, promotions *

- Availability of visual information about products *

- Availabilityof the entire menu of products

- Clear indication of locations of attendance

- Presence of an assistant receptionist in the external area

- Hygiene of the installations *

- Wait time in line until being attended at the cashier *

- Readiness of the receptionist (ready disposition for attendance)

- Courtesy and attendance of the receptionist

- Presentation of the receptionist (posture and appearance)

- Receptionists knowledge about products and procedures

- Possibility of adding extra ingredients to the lunches*

- Incorporation of new lunches/dishes to the menu
DIMENSION

Tangible

Assurance

Assurance

Tangible

Empathy

Empathy

Responsiveness

Tangible

Response

Assurance

Responsiveness

Responsiveness

Empathy

Tangible

Assurance

Responsiveness

Responsiveness 
Campos, D. F., Nóbrega, K. C.: Importance and the Zone of Tolerance of Customer Expectations of Fast Food Services

STAGES

Attendance at the cashie

Receive Order

Food Consumption
ATTRIBUTE

- Cashier readiness (ready disposition to attend to customers)

- Cashier presentation (posture and appearance)

- Courtesy and attentiveness at the cashier

- Cashier`s knowledge about products and procedures

- Form/terms of payment

- Order completed as asked (without errors)

- Price charged according to advertised

- Food price charged *

- Time spent being attended at the cashier

- Availability of change

- Distribution of complimentary gifts to children *

- Availabilityof waiting space at the counter

- Order of attendance panel

- Hygiene, preparation and handling of food *

- Wait time to receive food

- Food delivered as ordered (type x quantity)

- Availabilityof free additional sauces/seasonings *

- Availabilityof wait staff to bring food to tables

- Use of recyclable packaging *

- Regularity of the quality of food served

- Flavor of food served

- Texture and cooking of the food served

- Visual attractiveness of food served

- Aroma of food served

- Temperature of food served

- Quality of ingredients of food served

- Fat and calorie content of food served

- Availability of information on fat and calorie content *

\section{DIMENSION}

Responsiveness

Tangible

Empathy

Assurance

Response

Reliability

Reliability

Others

Responsiveness

Responsiveness

Empathy

Responsiveness

Tangible

Assurance

Responsiveness

Reliability

Responsiveness

Responsiveness

Assurance

Reliability

Reliability

Reliability

Reliability

Reliability

Reliability

Reliability

Reliability

Empathy

\section{Source: research}

\section{QUESTIONNAIRE}

The objectives of this research required that the perceptions of users regarding the importance of attributes and their expectations in relation to levels of desired service and the minimum acceptable service were found. The questionnaire was composed of three modules. In the first, questions are related to the socioeconomic profile of the respondents, their motivations, hours and frequency of use of the restaurants. The questionnaires were applied by students who participate in projects of scientific research in the University. The research coordinator trained these researchers, and some simulations were conducted at first. At the moment of the con- tact, the potential respondents were initially asked about their availability to answer the questions, as well as their frequency of using fast food restaurants. Based on a list of fast food restaurants present in the shopping center, the respondents were asked to mark those that they most frequented.

The questions relative to the questionnaire did not follow SERVQUAL model. In the second module, they were written in the form of a question: what importance do you give to the hygiene, preparation and handling of food? In the third module, the questions were constructed in the form of an imperative: on the scale, mark the value that best represents your expectation about the minimum level of quality that you would accept 
for the service of a fast food restaurant in the attributes of hygiene, preparation and handling of food.

In the second module, respondents manifested their perceptions about the degree of importance of each one of the 45 attributes presented in relation to the choice of a fast food restaurant in the shopping center. The responses were marked in a Likert scale of 11 points, varying from zero (not important) to ten (very important). In the third module, the expectations of the respondents regarding each of the 45 attributes used in the first module were found. Each respondent revealed his or her expectations about the level of quality that they would like to receive (desired level) and the minimum level of quality that would be acceptable (minimum level acceptable). The expectations were also found and measured by a Likert scale of 11 points, varying from zero (worse) to ten (excellent).

Once the attributes were identified using service cycle methodology, supported by fast food literature references, it was considered unnecessary a deep research aiming to validate the questionnaire. Although, a pre-test was completed with ten university students who frequented some of the fast food restaurants in the period of thirty days before that of the application. Small adjustments were made in the language, and formatting was necessary, in order to facilitate comprehension.

\section{THE SAMPLE}

The data were obtained using a sample of 500 students from a local private university. The interviews were completed on three different campuses of the university. Although the three campus show different distances from the shopping location, it is believed the distance causes no influence on results, once the studied shopping is the largest and most frequented in Natal, a city with approximately
800.000 inhabitants. Respondents' choices were not submitted to pre-planned criteria of sample stratification. Questionnaires were applied, for convenience, to the students present on campus and who volunteered to respond.

The application was only completed with the university students who customarily frequented some fast food restaurants on the list of restaurants in the shopping center. The use of a group of university students as a sample is convenient from the point of view of their homogeneity-young people with values associated with those held by fast food service providers, regarding efficient service, and also university students being in a category of subjects with formal education, and a sharpened critical sense (JOHNSON and MATHEWS, 1997; LEE and UGALDO, 1997; NILSSON-WITELL and FUNDIN, 2005; MACHADO et al, 2006; QIN and PRYBUTOK, 2009). Most likely, people of different social status, ages and backgrounds, would present different hierarchies of service attributes related to fast food. However, the central objective of the study is not to generalize the preferences observed in a sample of the population, but to demonstrate that a hierarchy of an attribute importance scale is compatible with the position ranking and of the width of tolerance zones found independently.

\section{RESULTS}

The results presented here reflect the ascertainment of 442 valid responses of 500 questionnaires applied, representing a rate of $88.4 \%$. The statistical treatment was completed using the Statistical Package for the Social Sciences -SPSS, 12.0 version. According to the results presented in Table 3 , the respondents are largely female $(69.2 \%)$, belonging to an age group between 18 and 24 years old (60\%) with a family income in the range of $R \$ 930$ to $R \$ 4,650$ (69.3\%). About $67.0 \%$ are exclusively students.

Table 3 - Distribution of the respondents by sex, age, income and occupation.

\begin{tabular}{|l|c|l|l|l|l|l|l|}
\hline \multicolumn{2}{|c|}{ Sex } & \multicolumn{2}{c|}{ Age } & \multicolumn{2}{c|}{ Family Income } & \multicolumn{2}{c|}{ Main Occupation } \\
\hline Masculine & $30.8 \%$ & Less than 18 & $1.8 \%$ & $\begin{array}{l}\text { Less than } \\
\text { R \$ 930 }\end{array}$ & $6.3 \%$ & Student & $66.3 \%$ \\
\hline Feminine & $69.2 \%$ & From 18 to 24 & $60.0 \%$ & $\begin{array}{l}\text { From R } 930 \\
\text { to R \$ 2,325 }\end{array}$ & $36.7 \%$ & Housewife & $0.7 \%$ \\
\hline & & From 25 to 35 & $31.9 \%$ & $\begin{array}{l}\text { From R } \$ 2,325 \\
\text { to R 4,650 }\end{array}$ & $32.6 \%$ & $\begin{array}{l}\text { Selfemployed } \\
\text { Professional }\end{array}$ & $2.7 \%$ \\
\hline
\end{tabular}


Campos, D. F., Nóbrega, K. C.: Importance and the Zone of Tolerance of Customer Expectations of Fast Food Services

\begin{tabular}{|l|l|l|l|l|l|l|c|}
\hline & & From 36 to 45 & $5.4 \%$ & $\begin{array}{l}\text { More than } \\
\text { R \$ 4,650 }\end{array}$ & $24.4 \%$ & Business owner & $3.8 \%$ \\
\hline & & More than 45 & $0.9 \%$ & & & Employee & 26.5 \\
\hline Total & $100 \%$ & Total & $100 \%$ & Total & $100 \%$ & Total & $100 \%$ \\
\hline
\end{tabular}

Source: research

They customarily eat at fast food restaurants in the shopping center at least once a month (84.2\%). Entertainment is the main circumstance in use of fast food services. Approximately $68 \%$ of the respondents go only to eat in the fast food restaurants, or they frequent them when they go to the cinema or window-shopping. The majority $(91.6 \%)$ customarily frequents the restaurants during lunch or dinner time, or between those meals. Table 4 shows the details of the distribution of respondents according to the variables presented.

Table 4 - Distribution of the respondents by circumstance, frequency level and hour.

\begin{tabular}{|c|c|c|c|c|c|}
\hline $\begin{array}{l}\text { Circumstances under which fast } \\
\text { food is used }\end{array}$ & $\%$ & $\begin{array}{l}\text { Frequency with which } \\
\text { attend fast food rest. }\end{array}$ & $\%$ & $\begin{array}{l}\text { Hours in which } \\
\text { fast food is used }\end{array}$ & $\%$ \\
\hline $\begin{array}{l}\text { Work in or around the shopping } \\
\text { center }\end{array}$ & $7.0 \%$ & Less than once a month & $15.8 \%$ & Before lunch & $1.6 \%$ \\
\hline Shoppers who stop to eat fast food & $18.3 \%$ & Once a month & $16.1 \%$ & Lunch & $30.7 \%$ \\
\hline $\begin{array}{l}\text { Window shoppers who stop to eat } \\
\text { fast food }\end{array}$ & $46.8 \%$ & Twice a month & $30.3 \%$ & $\begin{array}{l}\text { Between lunch } \\
\text { and dinner }\end{array}$ & $38.7 \%$ \\
\hline $\begin{array}{l}\text { Movie goers who stop to eat fast } \\
\text { food }\end{array}$ & $12.0 \%$ & Once a week & $21.5 \%$ & Dinner & $22.2 \%$ \\
\hline $\begin{array}{l}\text { Those going to the bank or other } \\
\text { services who stop to eat fast food }\end{array}$ & $2.9 \%$ & More than once a week & $16.3 \%$ & After dinner & $6.8 \%$ \\
\hline Those who go specifically to eat & $9.3 \%$ & & & & \\
\hline Others & $3.6 \%$ & & & & \\
\hline Total & $100 \%$ & Total & $100 \%$ & Total & $100 \%$ \\
\hline
\end{tabular}

Source: research

\section{THE PERCEPTION OF THE IMPORTANCE OF ATTRIBUTES}

The respondents indicated their perceptions relative to the importance of the attributes presented in Table 2, attributing a note of zero (not important) to 10 (very important) to each one, in a sequential and independent manner. The nominal measures ob- tained varied from 6.08 (level of frequency) to 9.37 (hygiene in preparation and food handling). A preliminary analysis permitted the assessment of what the respondents considered which attributes presented were of average importance to very important. Table 5 presents the median values obtained in the degree of importance of the ten first and ten last established.

Table 5-Degree of importance of the attributes from high to low.

\begin{tabular}{|l|c|c|l|c|c|}
\hline Attribute & $\begin{array}{c}\text { Measu } \\
\text { rement }\end{array}$ & Rank & Attribute & $\begin{array}{c}\text { Measu } \\
\text { rement }\end{array}$ & Rank \\
\hline Food hygiene & 9.37 & $\mathbf{1}$ & Indication of attendance locale & 7.81 & $\mathbf{3 6}$ \\
\hline
\end{tabular}




\begin{tabular}{|l|c|c|l|c|c|}
\hline Attribute & $\begin{array}{c}\text { Measu } \\
\text { rement }\end{array}$ & Rank & Attribute & $\begin{array}{c}\text { Measu } \\
\text { rement }\end{array}$ & Rank \\
\hline Installation hygiene & 9.33 & $\mathbf{2}$ & Location within the food court & 7.65 & $\mathbf{3 7}$ \\
\hline Food flavor & 9.31 & $\mathbf{3}$ & Staff to bring food to the table & 7.65 & $\mathbf{3 8}$ \\
\hline Food delivery with out errors & 9.21 & $\mathbf{4}$ & Additional ingredients & 7.55 & $\mathbf{3 9}$ \\
\hline Correct price & 9.19 & $\mathbf{5}$ & Visible product information & 7.52 & $\mathbf{4 0}$ \\
\hline Food texture & 9.14 & $\mathbf{6}$ & Visual attractiveness of store & 7.51 & $\mathbf{4 1}$ \\
\hline Orders with out errors & 9.10 & $\mathbf{7}$ & Receptionist presence & 7.27 & $\mathbf{4 2}$ \\
\hline Quality of the ingredients & 9.09 & $\mathbf{8}$ & Force of brand & 7.02 & $\mathbf{4 3}$ \\
\hline Time ofingredientsreceived & 8.93 & $\mathbf{9}$ & Freegifts to children & 6.46 & $\mathbf{4 4}$ \\
\hline Temperatureofthefood & 8.89 & $\mathbf{1 0}$ & Leveloffrequency & 6.08 & $\mathbf{4 5}$ \\
\hline $\begin{array}{l}\text { MEASUREMENT = Arithmetic } \\
\text { measurement of the degree of } \\
\text { perceptions of importance of } \\
\text { attributes. } \\
\begin{array}{l}\text { RANK = Ranking of the attributes } \\
\text { measured by importance. }\end{array}\end{array}$ & & & & & \\
\hline
\end{tabular}

Source: research

\section{EXPECTATION TOLERANCE ZONES}

The same attributes that received an evaluation of importance were presented to the respondents so that they express their expectations in relation to the levels of service desired and the minimum acceptable. Each attribute was associated to two equal scales from 111 points, varying from zero (the worst) to ten (excellent level of service). In the first, the respondent indicated the level of service desired (that he or she would like to receive) and the second, the minimum acceptable level of service.
For each attribute, using the algebraic expressions presented in section 3.2, the width of the tolerance zone (LargZ) and its height (AltZ) were calculated. The width of the tolerance zone varied from 1.38 (hygiene in the preparation and handling of food) to 2.50 (visual attractiveness of the store). On the other hand, the height of the tolerance zone-taken by the position of its median point-varied in minimum from 6.76 (level of frequency) to the maximum value of 8.63 (hygiene in the preparation and handling of food). Table 6 and 7 present the attributes with the greatest and the least scores in width and height of the zone.

Table 6-Attributes with width from the narrowest zone and the widest zone.

\begin{tabular}{|c|c|c|c|c|c|}
\hline ATTRIBUTE & $\mathbf{L a r g} \boldsymbol{Z}$ & RANK & ATTRIBUTE & Larg $\boldsymbol{R}$ & RANK \\
\hline Food hygiene & 1.38 & $\mathbf{1}$ & Promotional lunches & 2.00 & $\mathbf{3 6}$ \\
\hline Food flavor & 1.45 & $\mathbf{2}$ & Presence of the receptionist & 2.02 & $\mathbf{3 7}$ \\
\hline Correct price & 1.48 & $\mathbf{3}$ & Indication of attendance area & 2.03 & $\mathbf{3 8}$ \\
\hline Hygiene of the installations & 1.50 & $\mathbf{4}$ & Level of frequency & 2.17 & $\mathbf{3 9}$ \\
\hline Food texture & 1.51 & $\mathbf{5}$ & Distribution of free gifts for kids & 2.18 & $\mathbf{4 0}$ \\
\hline Delivery of food without errors & 1.55 & $\mathbf{6}$ & Visible product information & 2.26 & $\mathbf{4 1}$ \\
\hline Food temperature & 1.58 & $\mathbf{7}$ & Menu variety & 2.26 & $\mathbf{4 2}$ \\
\hline
\end{tabular}




\begin{tabular}{|c|c|c|c|c|c|}
\hline ATTRIBUTE & Larg $Z$ & RANK & ATTRIBUTE & Larg $Z$ & RANK \\
\hline Quality of the ingredients & 1.60 & $\mathbf{8}$ & Additional ingredients & 2.27 & $\mathbf{4 3}$ \\
\hline Aroma of the food & 1.61 & $\mathbf{9}$ & Force of the brand & 2.35 & $\mathbf{4 4}$ \\
\hline & 1.62 & $\mathbf{1 0}$ & Visual attractiveness of the store & 2.50 & $\mathbf{4 5}$ \\
\hline
\end{tabular}

Source: research

Table 7 -Attributes with the median position of the highest and lowest zones.

\begin{tabular}{|l|c|c|l|c|c|}
\hline \multicolumn{1}{|c|}{ ATTRIBUTE } & Alt $\boldsymbol{Z}$ & RANK & \multicolumn{1}{|c|}{ ATTRIBUTE } & Alt $\boldsymbol{Z}$ & RANK \\
\hline Food hygiene & 8.63 & $\mathbf{1}$ & Menu variety & 7.52 & $\mathbf{3 6}$ \\
\hline Food flavor & 8.61 & $\mathbf{2}$ & Fat/Calorie Information & 7.49 & $\mathbf{3 7}$ \\
\hline Correct Price & 8.60 & $\mathbf{3}$ & Staff to bring food to the table & 7.45 & $\mathbf{3 8}$ \\
\hline Hygiene of the installations & 8.45 & $\mathbf{4}$ & Presence of the receptionist & 7.40 & $\mathbf{3 9}$ \\
\hline Food texture & 8.45 & $\mathbf{5}$ & Additional ingredients & 7.39 & $\mathbf{4 0}$ \\
\hline Delivery of food without errors & 8.45 & $\mathbf{6}$ & Visible product information & 7.38 & $\mathbf{4 1}$ \\
\hline Food temperature & 8.43 & $\mathbf{7}$ & Visual attractiveness of the store & 7.31 & $\mathbf{4 2}$ \\
\hline Quality of the ingredients & 8.43 & $\mathbf{8}$ & Force of the brand & 7.04 & $\mathbf{4 3}$ \\
\hline Aroma of the food & 8.42 & $\mathbf{9}$ & Distribution of free gifts for kids & 6.83 & $\mathbf{4 4}$ \\
\hline Visual of the Food & 8.40 & $\mathbf{1 0}$ & Level of frequency & 6.76 & $\mathbf{4 5}$ \\
\hline Alt $\boldsymbol{Z}=$ Median height of tolerance zone. Rank= Ranking of the attributes by the height of the tolerance zone. \\
\hline
\end{tabular}

Source: research

From these findings we can visually affirm that among the ten best located in the ranking, in the three measurements, 8 of the most common attributes were assigned as: food hygiene, hygiene of the installations, quality of the ingredients, delivery without errors, correct price and flavor, texture and temperature of the food. Such findings offered, superficially, indications of the existence of a correlation between the dimensions of the measurements used.

\section{A COMPARISON OF THE RANKING}

Statistically it is possible to find the degree of the correlation between the measurements used, comparing it to the ranking generated by the three measurements used, and verifying if there is alignment between them. The alignment can then be found by the degree of the correlation that exists between the three rankings, compared two by two. A coefficient of correlation of
1.0 would indicate a degree of $100 \%$ alignment, a coefficient -1.0 would indicate complete (mis)alignment.

Cooper and Schindler (2003) point to the coefficients of correlation of Spearman and Kendall as the most utilized for the comparison of series of ranked values. The test of Spearman's correlation analyses the residues through the differences between the hierarchical positions of each variable. Spearman's coefficient would be equivalent to that of Pearson, applied to the rankings without, however, demanding the normal conditions of the population and the linear relation between the variables.

Table 8 shows the comparison of the three rankings obtained. The Spearman test revealed a high coefficient of correlation (0.93) among the ranking by the degree of importance conferred to the attributes with the ranking obtained by the hierarchy of the width of tolerance zones of the same attribute. 
Table 8-Comparison of the rankings obtained by the three measurements.

\begin{tabular}{|c|c|c|c|c|c|c|}
\hline Attribute & $\begin{array}{c}\text { Impor } \\
\text { tance }\end{array}$ & Rank & $\begin{array}{c}\text { Width } \\
\text { of Zone }\end{array}$ & Rank & $\begin{array}{l}\text { Height } \\
\text { of Zone }\end{array}$ & Rank \\
\hline Food hygiene & 9.37 & 1 & 1.38 & 1 & 8.63 & 1 \\
\hline Hygiene of the installation & 9.33 & 2 & 1.50 & 4 & 8.61 & 2 \\
\hline Food flavor & 9.31 & 3 & 1.45 & 2 & 8.60 & 3 \\
\hline Delivery of food without errors & 9.21 & 4 & 1.55 & 6 & 8.45 & 6 \\
\hline Correct prices & 9.19 & 5 & 1.48 & 3 & 8.42 & 9 \\
\hline Food textures & 9.14 & 6 & 1.51 & 5 & 8.45 & 4 \\
\hline Orders without errors & 9.10 & 7 & 1.67 & 12 & 8.43 & 8 \\
\hline Quality of ingredients & 9.09 & 8 & 1.60 & 8 & 8.45 & 5 \\
\hline Time it takes to receive food & 8.93 & 9 & 1.72 & 14 & 8.23 & 13 \\
\hline Food temperature & 8.89 & 10 & 1.58 & 7 & 8.43 & 7 \\
\hline \multicolumn{6}{|c|}{\begin{tabular}{|cc} 
Aroma of the food & 8.84 \\
$\mathbf{1 1}$ \\
1.61 \\
$\mathbf{9}$ \\
8.40
\end{tabular}} & 10 \\
\hline Food regularity & 8.81 & 12 & 1.64 & 11 & 8.23 & 14 \\
\hline Visual of the Food & 8.76 & 13 & 1.62 & 10 & 8.36 & 11 \\
\hline Price & 8.70 & 14 & 1.85 & 20 & 7.85 & 26 \\
\hline Time at the cashier & 8.68 & 15 & 1.80 & 15 & 8.04 & 15 \\
\hline Availability of change & 8.67 & 16 & 1.69 & 13 & 8.25 & 12 \\
\hline Receptionist knowledge & 8.64 & 17 & 1.81 & 16 & 7.97 & 18 \\
\hline Receptionist courtesy/attention & 8.63 & 18 & 1.84 & 18 & 7.93 & 20 \\
\hline Cashier readiness & 8.51 & 19 & 1.90 & 28 & 8.01 & 16 \\
\hline Cashier courtesy/attention & 8.49 & 20 & 1.82 & 17 & 7.90 & 22 \\
\hline Wait time in line & 8.46 & 21 & 1.96 & 32 & 7.95 & 19 \\
\hline Use of recycleable materials & 8.44 & 22 & 1.87 & 22 & 7.85 & 25 \\
\hline Promotional lunches & 8.39 & 23 & 2.00 & 36 & 7.92 & 21 \\
\hline Receptionist readiness & 8.33 & 24 & 1.89 & 27 & 7.84 & 28 \\
\hline Receptionist presentation & 8.26 & 25 & 1.84 & 19 & 7.72 & 32 \\
\hline Cashier knowledge & 8.25 & 26 & 1.86 & 21 & 7.99 & 17 \\
\hline Order served signage & 8.22 & 27 & 1.89 & 25 & 7.74 & 30 \\
\hline Fat/Calorie content & 8.17 & 28 & 1.99 & 35 & 7.65 & 34 \\
\hline Form and time of payment & 8.14 & 29 & 1.89 & 26 & 7.87 & 24 \\
\hline Cashier presentation & 8.13 & 30 & 1.87 & 23 & 7.85 & 27 \\
\hline Incorporation of new lunches & 8.11 & 31 & 1.97 & 33 & 7.69 & 33 \\
\hline Waiting space at the counter & 8.03 & 32 & 1.95 & 31 & 7.88 & 23 \\
\hline Varied menu & 7.87 & 33 & 2.26 & 42 & 7.52 & 36 \\
\hline Free additional seasonings & 7.85 & 34 & 1.94 & 30 & 7.75 & 29 \\
\hline Fat/Calorie information & 7.84 & 35 & 1.90 & 29 & 7.49 & 37 \\
\hline Indication of attendance areas & 7.81 & 36 & 2.03 & 38 & 7.55 & 35 \\
\hline Location in the food court & 7.65 & 37 & 1.88 & 24 & 7.72 & 31 \\
\hline
\end{tabular}




\begin{tabular}{|l|c|c|c|c|c|c|}
\hline \multicolumn{1}{|c|}{ Attribute } & $\begin{array}{c}\text { Impor } \\
\text { tance }\end{array}$ & Rank & $\begin{array}{c}\text { Width } \\
\text { of Zone }\end{array}$ & Rank & $\begin{array}{c}\text { Height } \\
\text { of Zone }\end{array}$ & Rank \\
\hline Staff to bring food to the table & 7.65 & $\mathbf{3 8}$ & 1.97 & $\mathbf{3 4}$ & 7.45 & $\mathbf{3 8}$ \\
\hline Additional extra ingredients & 7.55 & $\mathbf{3 9}$ & 2.27 & $\mathbf{4 3}$ & 7.39 & $\mathbf{4 0}$ \\
\hline Visible product information & 7.52 & $\mathbf{4 0}$ & 2.26 & $\mathbf{4 1}$ & 7.38 & $\mathbf{4 1}$ \\
\hline Visual attractiveness of the store & 7.51 & $\mathbf{4 1}$ & 2.50 & $\mathbf{4 5}$ & 7.31 & $\mathbf{4 2}$ \\
\hline Receptionist presence & 7.27 & $\mathbf{4 2}$ & 2.02 & $\mathbf{3 7}$ & 7.40 & $\mathbf{3 9}$ \\
\hline Force of the brand & 7.02 & $\mathbf{4 3}$ & 2.35 & $\mathbf{4 4}$ & 7.04 & $\mathbf{4 3}$ \\
\hline Distribution of free gifts for kids & 6.46 & $\mathbf{4 4}$ & 2.18 & $\mathbf{4 0}$ & 6.83 & $\mathbf{4 4}$ \\
\hline Level of frequency & 6.08 & $\mathbf{4 5}$ & 2.17 & $\mathbf{3 9}$ & 6.76 & $\mathbf{4 5}$ \\
\hline
\end{tabular}

Source: research

In comparison of the ranking by the degree of importance with the ranking obtained by the hierarchy of the heights of the tolerances zones, the coefficient of correlation was still greater, with the value of 0.96 . The coefficients are significant to $\alpha=0.01$.

Table 9-Coeffiecient of the correlations obtained by the Spearman and Pearson Tests.

\begin{tabular}{|l|c|c|c|}
\hline \multicolumn{2}{|c|}{ Correlation Coefficients } \\
Ranking & Importance & $\begin{array}{c}\text { Width of the } \\
\text { Tolerance Zone }\end{array}$ & $\begin{array}{c}\text { Height of the } \\
\text { Tolerance Zone }\end{array}$ \\
\hline Importance & $\mathbf{1 . 0 0}$ & $\mathbf{0 . 9 3}$ & $\mathbf{0 . 9 6}$ \\
\hline Width of Tolerance Zone & $\mathbf{0 . 9 3}$ & $\mathbf{1 . 0 0}$ & $\mathbf{0 . 9 2}$ \\
\hline Altura da Zona de Tolerância & $\mathbf{0 . 9 6}$ & $\mathbf{0 . 9 2}$ & $\mathbf{1 . 0 0}$ \\
\hline $\begin{array}{l}\text { Nominal Values } \\
\text { Pearson Test }\end{array}$ & Importance & $\begin{array}{c}\text { Width of the } \\
\text { Tolerance Zone }\end{array}$ & $\begin{array}{c}\text { Height of the } \\
\text { Tolerance Zone }\end{array}$ \\
\hline Importance & $\mathbf{1 . 0 0}$ & $\mathbf{- 0 . 8 5}$ & $\mathbf{0 . 9 7}$ \\
\hline Width of Tolerance Zone & $\mathbf{- 0 . 8 5}$ & $\mathbf{1 . 0 0}$ & $\mathbf{- 0 . 9 1}$ \\
\hline Height of Tolerance Zone & $\mathbf{0 . 9 7}$ & $\mathbf{- 0 . 9 1}$ & $\mathbf{1 . 0 0}$ \\
\hline
\end{tabular}

Source: research

The results suggest, however, the confirmation of the two affirmations by Zeithaml and Bitner (2003) such that: attributes that are more important to customers have a narrower tolerance zone and have limits of expectations closer to the maximum in the scale used. The coefficient of $0.92(\alpha=0.01)$ shows, how corollary, which is the correlation between the orderings and the width and height of the tolerance zone attributes, i.e. attributes with a narrower tolerance zone, are positioned closer to the maximum of the measuring scale of expectations.

The Pearson test applied to the nominal values of the medians obtained for importance, width and height of attribute tolerance zones reaffirm the alignment of the measurements. The coefficients of the negative correlations $(-0.85$ and $-0.9, \alpha=0.01)$ suggest that the width of the tolerance zone has the inverse behavior to the importance of the attributes, as well as the height of the zone. As expected, the correlation of the height of the zone with the importance of the attributes was direct $(0.97, \alpha=0.01)$. The results of the tests of correlations are presented in Table 9.

\section{CONCLUSIONS}

As theoretical implications, empirical studies involving instruments and methodologies of management help to strengthen the base of application. By 
its very nature, the management of service quality deals with processes of evaluation with an elevated degree of subjectivity. The appreciation of variables present in the service encounters requires instruments and scales of measuring that have the capacity to measure perceptions and expectations, both derived from complex mental processes that vary from individual to individual. Empirically confirming the hypothesis raised by the works of Zeithaml et al (1993) and Zeithaml and Bitner (2003), this study reinforces relationships aimed at measurements, studied in the naturally expressed field, to evaluate the subjective character of the impact of service on individuals. The empirical results of the research confirm the hypothesis developed. The coefficients of the correlation obtained reached values near or higher to 0.90 , to the level of significance of $1 \%$.

As an underlying consequence of the study, the results allow us to identify the most important attributes of fast food service, evaluated over a sample of a population of its main consumers (KARA et al, 1997; NICK and HOWARD, 1998; BOJANIC, 2007; BOURANTA et al, 2009). And it is important to observe that, with a base in any one of the measurements - importance, width and height of the zone -it is possible to find that the attributes most valued reflect the essentials of fast food service: the food (quality of the ingredients, regularity, flavor, texture, aroma, visual and temperature), hygiene (in the installations, and food prep and handling), correct registering of orders and price, correct delivery of order and time of attendance. This tendency is also observed in the study of Machado et al (2006). Among the least valued, on the other hand, appear attributes like the force of the brand, visual attractiveness of the store, level of frequency, distribution of complimentary gifts, presence of the receptionist and availability of staff to take the lunch to the tables.

As managerial implications it may be cited that companies should concentrate efforts on food, hygiene, service absent of mistakes and service speed rather than investing on brand, visual attractiveness of the store, complimentary gifts, availability of staff to take the lunch to the tables - these last use to be cited, in a practical sense, as of greater importance. Another opportunity for companies is to investigate more their own customers' point of view, as this occurred in the present study.

There are limitations in the present study regarding possible generalizations of the results obtained with the levels of expectations about the attributes for the population as a whole, as this was not the central ob- jective of the study. Cultural factors, price, urgency, first use, or renovation, can influence the limits of the tolerance zone. In the field of results referring to the empirical validation of the hypothesis, the numerical differences between the measurements, when held up to the sample errors, can provoke rank changes of the attributes evaluated. The changes in position of the attributes in the ranking can contribute to the improvement of the correlation as well as its misalignment.

New investigative studies can reveal important connections associated to the service encounters or moments of truth, especially when compared to initial vs. final moments, and central vs. auxiliary services. Or, still, when compared to moments with the classical dimensions of service such as reliability, assurance, responsiveness, empathy and tangibility. Another opportunity for deeper investigations refer to the use of a broader sample, including not only university students, but also fast food at the very moment and right after the moment of consumption, with interviews performed at the very shopping.

\section{REFERENCES}

AHMED, S. Measuring service quality of a public university library in bangladesh using servqual. Performance Measurement and Metrics, v. 10, n. 1, p. 17-32, 2009.

BAEK, S.;HAM, S.;YANG, I. A cross-cultural comparison of fast food restaurant selection criteria between korean and filipino college students. International Journal of Contemporary Hospitality Management. v. 25, p. 683-698, 2006.

BEHARA, R.S.; FISHER, W.W.; LEMMINK, J., "Modelling and evaluating service quality measurement using neural networks", International Journal of Operations \& Production Management, v. 22 n. 9/10, p. 1162-85, 2002.

BITNER, M.; HUBBERT, A.; ZEITHAML, V. Customer contributions and roles in service delivery. International Journal of Service Industry Management, v.8, n.3, p.193-205, 1997.

BITNER, M.J.; BROWN, S.W., Technology infusion in service encounters, Journal of the Academy of Marketing Science, v. 28 n. 1, p. 138-49, 2000.

BOJANIC, D. C. Customer profile of the "carryout" segment for restaurants. International Journal of Contemporary Hospitality Management.v.19 , n. 1, p. 21-31, 2007

BOURANTA, N.; CHITIRIS, L.; PARAVANTIS. The relationship between internal and external servicequality. International Journal of Contemporary Hospitality Management. v. 21, n. 3, p. 257-293, 2009.

BRADY, M.; ROBERTSON, C. An exploratory study of service value in the USA and Ecuador. International Journal of Service Industry Management, v. 10, n. 5, p. 469-486, 1999. 
BROWN, T. Using norms to improve the intrepretation of service quality measures. The Journal of Services Marketing. v. 11, n. 1, p. 66-80, 1997.

CAVANA, R.; CORBETT, L. Developing zones of tolerance for managing passenger rail service quality. International Journal of Quality \& Reliability Management, v. 24, n. 1, p. 7-31, 2007.

CHIOU, H.K.; TZENG, G.H.; CHENG, D.C., Evaluating sustainable fishing development strategies using fuzzy MCDM approach, Omega, v. 33, p. 223-34, 2005

COOPER, D.; SCHINDLER, P. Métodos de Pesquisa em Administração. Ed. Bookman Porto Alegre, 2003.

COX, A.D.; COX, D.; ANDERSON, R.D. Reassessing the pleasure of store shopping, Journal of Business Research, v. 58, n. 3, p. 250-9, 2003.

COYE, R.W., Managing customer expectations in the service encounter, International Journal of Service Industry Management, v. 15, n. 1, p. 54-71, 2004.

CRONIN, J. Jr; TAYLOR, A.S. Measuring service quality: a reexamination and an extension, Journal of Marketing, v. 56, n. 3, p. 55-67. 1992.

DENG, W. Fuzzy importance-performance analysis for determining critical service attributes, International Journal of Service Industry Management, v. 19, n. 2, p. 252-270, 2008.

FITZSIMMONS, J. A.; FITZSIMMONS, M.J., Administração de Serviços - operações, estratégias e tecnologia da informação, Porto Alegre: Bookman. 2005.

GILBERT, G.; VELOUTSOU, C.; MOUTINHO, L. Measuring customer satisfaction in the fast food industry: a cross-national approach. Journal of Services Marketing. v. 18, n. 5, p. 371383, 2004.

GOYAL, A.; SINGH, N.P. Consumer perception about fast food in India: an exploratory study. British Food Journal, v. 109, n. 2, p. 182-195. 2007.

GRÖNROOS, C. Strategic Management and marketing in the service sector, Helsinki/Helsingfors: Swedish School of Economics, Finland, 1982.

GRÖNROOS, C. Marketing, gerenciamento e serviços: a competição por serviços na hora da verdade, Rio de Janeiro: Campus, 1995.

GUPTA, A.; CHEN, I. Service quality: implications for management development. International Journal of Quality \& Reliability Management. v. 12, n. 7, p. 28-35, 1995.

HARRIS, R.; KIM, H.; BARON, S. Theatrical service experiences dramatic script development with employees. International Journal of Service Industry Management, v. 14 n. 2, p. 18499, 2003

JOHNSON, C.; MATHEWS, B.P.The influence of experience on service expectations. International Journal of Service Industry Management. v. 8, n. 4, p. 290-305, 1997.

JOHNSTON, R. The zone of tolerance exploring the relationship between service transactions and satisfaction with the over- all service. International Journal of Service

Industry Management, v. 6 n. 2, p. 46-61, 1995.

KARA, A.; KAYNAK, E.; KUCUKEMIROGLU, O. Marketing strategies for fast-food restaurants: a customer view. International Journal of Contemporary Hospitality Management.v. 7, n. 4, p.16-22. 1995

KENG, C. J. et al. Modeling service encounters and customer experiential value in retailing An empirical investigation of shopping mall customers in Taiwan. International Journal of Service Industry Management. v. 18, n. 4, p. 349-367, 2007.

LAW, A.K.Y.; HUI, Y.V.; ZHAO, X. , A. Modeling repurchase frequency and customer satisfaction for fast food outlets. International Journal of Quality \& Reliability Management. v. 21, n. 5, p. 545-563, 2004.

LEE, M.; ULGADO, F.M. Consumer evaluations of fast-food services: a cross-national comparison. The Journal of Services Marketing. v. 11, n. 1, p.39-52, 1997.

LILJANDER, V.; STRANDVIK, T. The nature of customer relationships in services. Advances in Services Marketing and Management. The JAI Press, p. 143, 1995.

LIU, C.; CHEN, K., A. A look at fast food competition in the Philippines. British Food Journal. v. 102, n. 2, p. 122-133, 2000.

LOVELOCK, C. W., J. Marketing de serviços.São Paulo: Prentice Hall Brasil. 2006.

MACHADO, M.D.; QUEIROZ, T.R.; MARTINS, M.F. Mensuração da qualidade de serviço em empresas de fastfood. Gestão\&Produção, v.13, n. 2, p. 261-270, 2006.

MERSHA, T.; ADLAKHA, V. Attributes of service quality: the consumer's perspective. International Journal of Service Industry Management.v.3, n.3, p. 34-45. 1992

NADIRI, H. Diagnosing the zone of tolerance for hotel services. Journal of Services Marketing, v. 21, n. 2, p. 137-148, 2007.

NILSSON-WITELL, L.; FUNDIN. A. Dynamics of service attributes: a test of Kano's theory of attractive quality .International Journal of Service Industry Management. v. 16, n. 2, p. $152-168,2005$

NICK, J.; HOWARD, A. Customer expectations versus perceptions of service performance in the food service industry. . International Journal of Service Industry Management. v. 9, n. 3, p. 248-265, 1998.

NÓBREGA, K. C. Gestão da Qualidade em Serviços. Escola Politécnica - Departamento de Engenharia de Produção, Universidade de São Paulo, São Paulo, 1997.

NORMANN, R. Service Management: Strategy and Leadership in Service Business. New York: John Wiley Professional. 2001.

PARASURAMAN, A.; ZEITHAML, V.; BERRY, L. A conceptual model of service quality and its implications for future research, Journal of Marketing, v. 49 n. 4, p. 41-50, 1985.

PARASURAMAN, A.; ZEITHAML, V.; BERRY, L. Servqual: a 
multiple-item scale for measuring consumer perception of service quality, Journal of Retailing, v. 64 n. 1, 1988.

PARASURAMAN, A.; ZEITHAML, V..; BERRY, L. Reassessment of Expectations as a Comparison Standard in Measuring Service Quality: Implications for Further Research, Journal of Marketing, v. 58, p. 111-124, 1994.

PRICE, S.The new faces of the fast food market? The potential for consortia in pizza home delivery. British Food Journal,v.99, n.11, p.438-446, 1997.

QIN, H.; PRYBUTOK, V. Service quality, customer satisfaction, and behavioral intentions in fast food restaurants. International Journal of Quality and Service Sciences. v. 1, n. 1, p. 78-95, 2009.

WIRTZ, J.; MATTILA, A. The impact of expected variance in performance on satisfaction process. International Journal of Service Industry Management, v. 12, n. 4, p. 342-358, 2001.

YANG, Z.; JUN, M.; PETERSON, R. Measuring customer perceived online service quality: scale development and managerial implications. International Journal of Operations \& Production Management, v .24, n. 11/12, p.1149-74, 2004.

YAP, K.; SWEENEY, J. Zone-of-tolerance moderates the service quality-outcome relationship. Journal of Services Marketing, v. 21, n. 2, p. 137-148, 2007.

ZEITHAML, V.; BERRY, L.; PARASURAMAN, A. The nature and determinants of customer expectations of service. Journal of Academy of Marketing Sciences, v. 21, n. 1, p. 1-12, 1993.

ZEITHAML, V. A.; BITNER, M. J., Marketing de serviços: a empresa com foco no cliente, Ed. Bookman, Porto Alegre, 2003.

\section{AUTHOR'S BIOGRAPHY}

Domingos Fernandes Campos is Professor of Operations and Supply Chain Management at the UnP - Potiguar University, Natal, Brazil. He earned his Ph.D. degree in Production Engineering from the Polithecnical University of Madrid, Spain (1989). He is a Senior Consultant with a large experience in works for Manufacturing and Logistics companies. His main research interests are Distribution, Logistics Service and Operations Management.

Kleber C Nóbrega, Mechanical Engineer, concluded his Master Degree in Operations Engineering, 1990, at Federal University of Santa Catarina. After that he got his Doctoring Degree at EscolaPolitecnicaUniversity of São Paulo, in 1997. Kleber is nowadays professor at Business Management Professional Mastering Program, in Potiguar University, located in Natal, Rio Grande do Norte, Brazil, where he has been responsible for the disciplines of Strategic Management and Service Operations Management. Kleber has worked as consultant in Strategic Planning and Management, Service Management, Service Quality, and Quality Systems. 